\title{
Variation in the lipid content and composition of Antarctic krill Euphausia superba at South Georgia
}

\author{
David Pond $^{1, *}$, Jon Watkins ${ }^{2}$, Julian Priddle ${ }^{2}$, John Sargent ${ }^{1}$ \\ ${ }^{1}$ Department of Biological and Molecular Sciences, University of Stirling, Stirling FK9 4LA, United Kingdom \\ ${ }^{2}$ British Antarctic Survey, NERC, High Cross, Madingley Road, Cambridge CB3 0ET, United Kingdom
}

\begin{abstract}
Samples of Antarctic krill Euphausia superba Dana from 8 sites around South Georgia were analysed for total lipid and lipid class composition. Samples consisted predominantly of immature krill, and females were entirely absent from samples from 2 of the 8 sites studied. Individual fresh mass varied from 0.16 to $1.72 \mathrm{~g}$ [median values of $0.47 \mathrm{~g}(0.16$ to 0.94$), 1.14 \mathrm{~g}(0.71$ to 1.63$)$ and $1.46 \mathrm{~g}(0.94$ to 1.72) for immatures, males and females respectively]. Lipid amounts varied from 5 to $147 \mathrm{mg}^{\text {ind. }}{ }^{-1}$ [median values of $17.8 \mathrm{mg}$ (5.1 to 64.2$), 21.0 \mathrm{mg} \mathrm{(9.3} \mathrm{to} 87.7$ ) and $70.3 \mathrm{mg}$ (17.3 to 146.9) for immatures, males and females respectively]. Triacylglycerol (TAG) and phosphatidylcholine were the 2 most abundant lipid classes in all krill. Multivariate analysis of lipid composition indicated significant overlap between sex-maturity classes, although female krill tended to be distinguished from males by higher proportions of TAG and lower proportions of phosphatidylserine plus phosphatidylinositol. Reproductive investment is implicated in the overall variability in lipid content and composition, with females containing high lipid levels as reserves for egg production, whilst males showed apparent lipid deficits resulting from short-term mobilisation of storage material for spermatophore production and attachment. Significant and systematic site-to-site variability in lipid content and composition were evident in the samples and this could not be explained by the sex ratio or krill size.
\end{abstract}

KEY WORDS: Euphausia superba $\cdot$ Krill $\cdot$ Lipid class $\cdot$ Multivariate analysis $\cdot$ Reproductive investment

\section{INTRODUCTION}

Lipids are substantial components of pelagic marine food webs, especially in polar regions where organisms are generally very rich in lipid (Falk-Petersen et al. 1990), and serve 2 crucial functions. First, lipids are an efficient source of metabolic energy. Second, lipids and especially the so-called essential polyunsaturated fatty acids have vital structural and functional roles in cell membranes and are, therefore, required for growth and reproduction. Consumers derive all their lipid requirements either from their diet or by endogenous lipogenesis from dietary protein and carbohydrate precursors. In addition dietary lipid may be modified by animals before it is utilised for metabolism or for the synthesis of cell membranes. As

\footnotetext{
- Present address: Plymouth Marine Laboratory, Prospect
} Place, Plymouth PL1 3DH, United Kingdom lipids are major biochemical constituents of most marine organisms and lipid composition can be related to taxonomy, lipids can be used to study trophic interactions between marine consumers and their food supply (Sargent et al. 1987).

Antarctic krill Euphausia superba Dana are an important component in the Southern Ocean ecosystem, and their size and swarming behaviour make them available as food for a wide range of seabirds, marine mammals, fish and squid (Laws 1985). During the austral summer, krill are primarily herbivorous, feeding mostly on diatoms and small flagellates (Marr 1962, Clarke 1980, Antezana et al. 1982, Price et al. 1988). Growth is rapid at this time - up to $1 \mathrm{~mm} \mathrm{wk}^{-1}$ (Mauchline 1980, Kanda et al. 1982, Clarke \& Morris 1983). Metabolic rate is high, partly because the animal is negatively buoyant and needs to swim continuously to remain within the upper few hundred metres of the water column (Kils 1979, Clarke \& Morris 1983). Krill energy requirements have been estimated to be approximately 17 to $28 \%$ of 


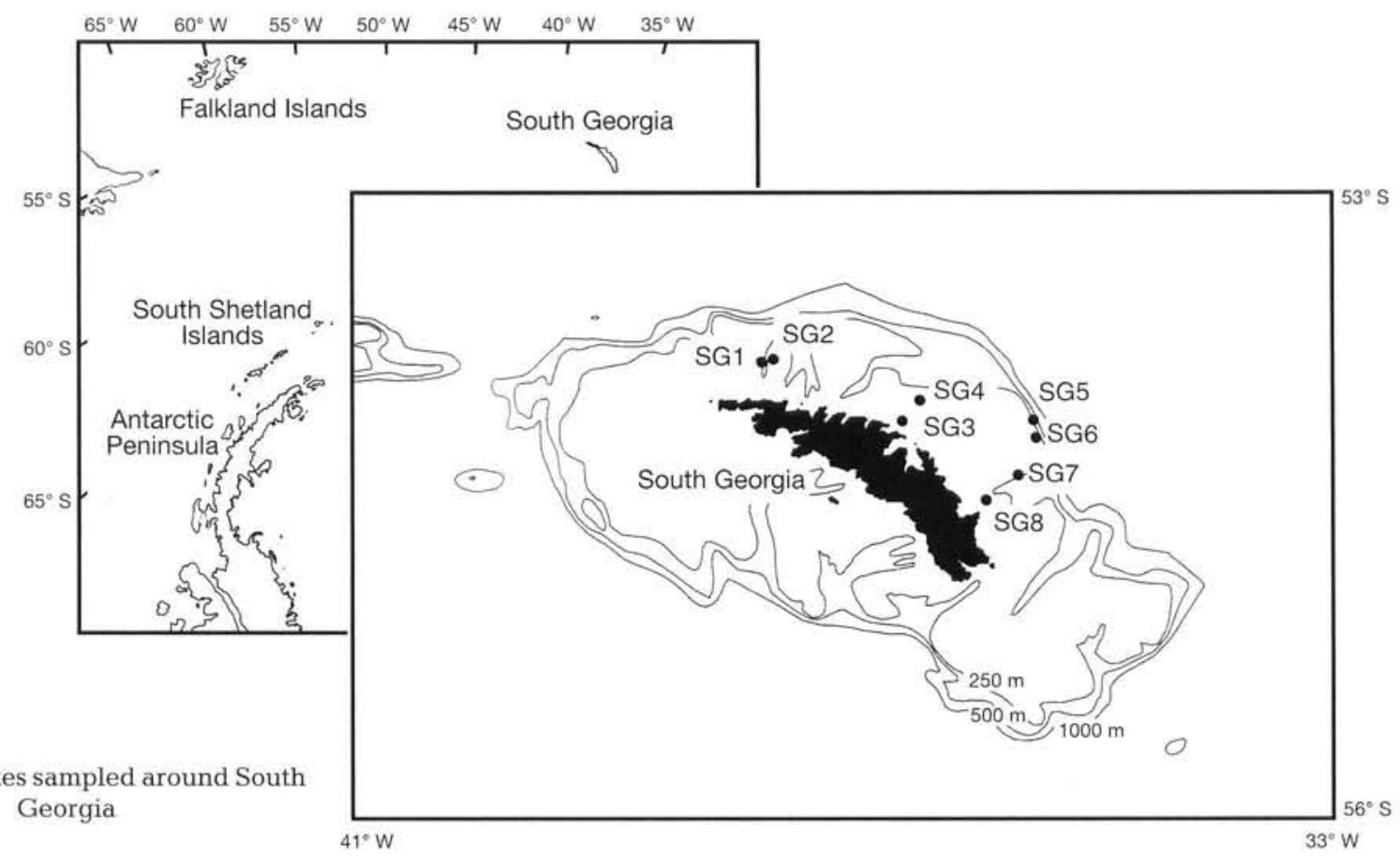

body mass per day (Quetin et al. 1993), which are similar to values for other euphausiids. Although krill store significant quantities of lipid, this is unlikely to be sufficient to sustain the animal during winter, when the normal food supply is low (Quetin et al. 1993). During winter, krill may adopt a more varied diet, for instance feeding on ice microbiota, on smaller zooplankton such as copepods, or benthically (Clarke 1980, Hagen 1988, Marschall 1988, Price et al. 1988). Metabolism may also be reduced and growth in winter can become negligible (Morris \& Priddle 1984, Rosenberg et al. 1986, McClatchie 1988) and even negative (Ikeda \& Dixon 1982, Ettershank 1983).

Krill productivity, and particularly reproductive effort, is directly related to both the quantity and quality of microplankton in the krill's immediate environment (Ross \& Quetin 1986). Moreover, since krill appears to be a repeat summer spawner at least in some areas, spawning frequency is probably related directly to food availability (Clarke \& Morris 1983, Ross \& Quetin 1986). Therefore, to advance understanding of krill productivity we need to quantify the availability of microplanktonic lipid throughout the austral summer season together with its rate of ingestion and assimilation by krill. The present investigation extends a recent study (Pond et al. 1993) by determining the lipid composition of 3 different sexual maturity stages of krill.
The objective is to investigate the roles of lipid in krill metabolism in general and in reproduction in particular.

\section{MATERIALS AND METHODS}

Sampling. Samples of phytoplankton and krill were collected during a cruise of RRS 'John Biscoe' off South Georgia during January and February 1991 (Fig. 1). For a more comprehensive description of study sites see Pond et al. (1993). Results for some environmental variables at the sites are presented in Table 1. Samples were obtained with a rectangular mid-water trawl (RMT8) of nominal mouth area $8 \mathrm{~m}^{2}$ which was trawled obliquely from $200 \mathrm{~m}$ depth to the surface. The RMT8 comprised 3 nets, each of which was fished sequentially for $20 \mathrm{~min}$.

Table 1. Environmental variables at the 8 sites around South Georgia

\begin{tabular}{|c|c|c|c|c|c|c|}
\hline Site & $\begin{array}{l}\text { Date } \\
(1991)\end{array}$ & $\begin{array}{l}\text { Depth range } \\
\text { fished (m) }\end{array}$ & $\begin{array}{l}\text { Temp. } \\
\left({ }^{\circ} \mathrm{C}\right)\end{array}$ & $\begin{array}{l}\text { Salinity } \\
\text { (psu) }\end{array}$ & $\begin{array}{l}\text { Chlorophyll a } \\
\left(\mu \mathrm{g}^{-1}\right)\end{array}$ & $\begin{array}{c}\text { Fatty acids } \\
\qquad\left(\mu \mathrm{g} \mathrm{l}^{-1}\right)\end{array}$ \\
\hline SG1 & 19 Jan & $0-130$ & 2.4 & 33.9 & 1.24 & 195.4 \\
\hline SG2 & 19 Jan & $18-25$ & 2.4 & 33.9 & - & - \\
\hline SG3 & 24 Jan & $5-110$ & 1.7 & 34.0 & 2.45 & 187.8 \\
\hline SG4 & 25 Jan & $9-170$ & 1.8 & 34.0 & 1.69 & 37.4 \\
\hline SG5 & 8 Feb & $0-185$ & - & - & 0.63 & 133.2 \\
\hline SG6 & $8 \mathrm{Feb}$ & $5-160$ & 2.0 & 34.0 & - & - \\
\hline SG7 & 12 Feb & $0-218$ & - & - & - & - \\
\hline SG8 & 13 Feb & $0-200$ & - & - & 0.26 & 58.2 \\
\hline
\end{tabular}


Selection and storage. Krill were not sampled randomly from the nets, but were selected according to sex and maturity. The krill were blotted dry on filter paper to remove excess sea water, adhering copepods were removed manually with tweezers and individual specimens were then frozen in pre-weighed, self-sealing plastic bags at $-60^{\circ} \mathrm{C}$ until analyses up to $20 \mathrm{mo}$ later in the UK. Samples remained in good condition as indicated by the low levels of free fatty acids $(<15 \%$ of total lipid) and high polyunsaturated fatty acid content (Pond 1994).

Lipid analyses. After weighing, total lipid was extracted separately from the krill body and gut (hepatopancreas and stomach: Henderson et al. 1981) using chloroform: methanol $(2: 1 \mathrm{v} / \mathrm{v})$ according to Folch et al. (1957). Total lipid extracts in chloroform:methanol were dried under nitrogen and in vacuo at room temperature until constant weight. Samples were stored in small volumes of chloroform: methanol at $-20^{\circ} \mathrm{C}$ until further analysis.

Total lipid was fractionated into individual neutral and polar classes by thin layer chromatography (TLC) on $10 \times 10 \times 0.25 \mathrm{~cm}$ high-performance TLC plates of silica gel using the 2solvent system described by. Olsen \& Henderson (1989). Lipid classes (see Table 2) were identified by comparison with known standards run on the same plates and determination by quantitative densitometry after spraying the plates with $8 \%(\mathrm{v} / \mathrm{v})$ phosphoric acid containing $3 \%(\mathrm{w} / \mathrm{v})$ copper acetate followed by charring at $160^{\circ} \mathrm{C}$ for 15 min (Olsen \& Henderson 1989).

Statistical analysis. Data were analysed using the MINITAB statistical package (Ryan et al. 1988). Principal components were generated from a correlation matrix of the percentage contributions of lipid classes for all krill at each site.

\section{RESULTS AND DISCUSSION}

\section{Krill sex distribution and size}

A total of 165 individual krill from 8 sites around South Georgia (SG1 to SG8) were analysed in the present study. There was an overall predominance of immature krill at all 8 sites and a total of 76 individuals of this category were analysed (Fig. 2). Although the population sampled from an indi- vidual net haul may not accurately represent the local population (Watkins et al. 1986), the overall composition of krill at these sites will reflect the gross features of the area. Mature male and female krill were relatively scarce and only 48 and 41 of these animals were analysed respectively. Indeed, at SG7 and SG8 female krill appeared to be totally absent as none were found in the RMT8 hauls, despite a deliberate search for representatives of all 3 sex and maturity classes.

Females were generally the largest individuals of the 3 categories of krill at all sites, ranging from 0.94 to $1.72 \mathrm{~g}$ wet mass (median value $1.46 \mathrm{~g}$; Fig. 3a). Male krill tended to be slightly smaller than the females, ranging from 0.71 to $1.68 \mathrm{~g}$ with a median wet mass of $1.15 \mathrm{~g}$. Corresponding values for immatures were a median fresh mass of $0.47 \mathrm{~g}$ and range 0.16 to $0.94 \mathrm{~g}$. However, there was overlap in the ranges of body mass for the 3 categories, especially between males and females (Fig. 3a). At individual sites the ranking of sex and maturity classes by size was the same as that of the overall sample, with median fresh mass ranging from 1.30 to $1.68 \mathrm{~g}$ for females, 0.82 to $1.45 \mathrm{~g}$ for males and
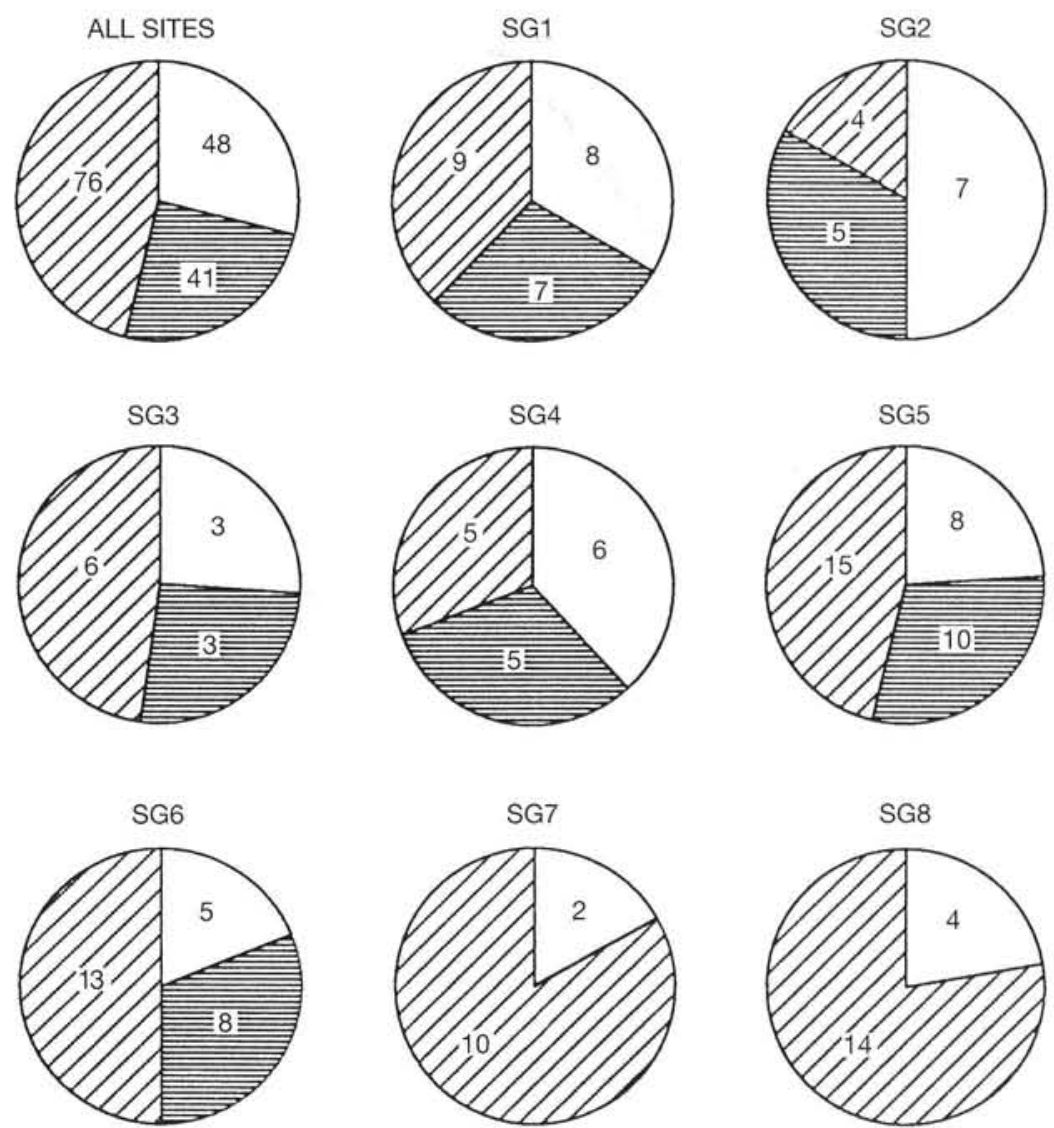

Fig. 2. Euphausia superba. Proportions and numbers of males ( $\square$ ), females (目) and immatures $(\square)$ selected from the samples at the 8 South Georgia sites. Note that values do not necessarily correspond to the composition of the local populations (see Watkins et al. 1986) 
a

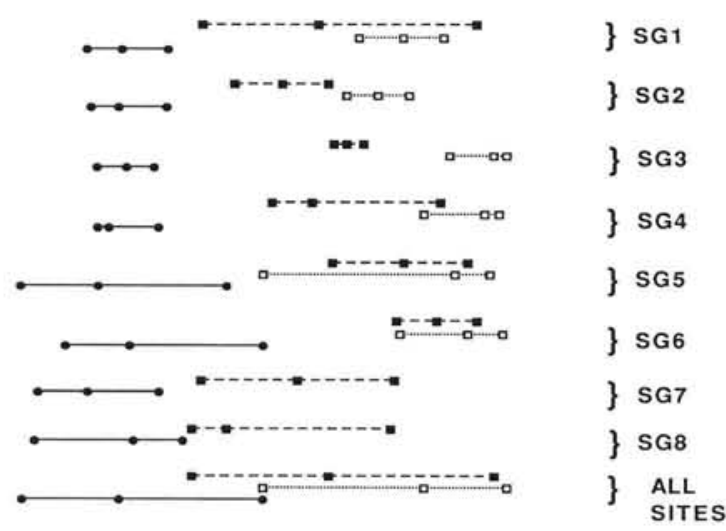

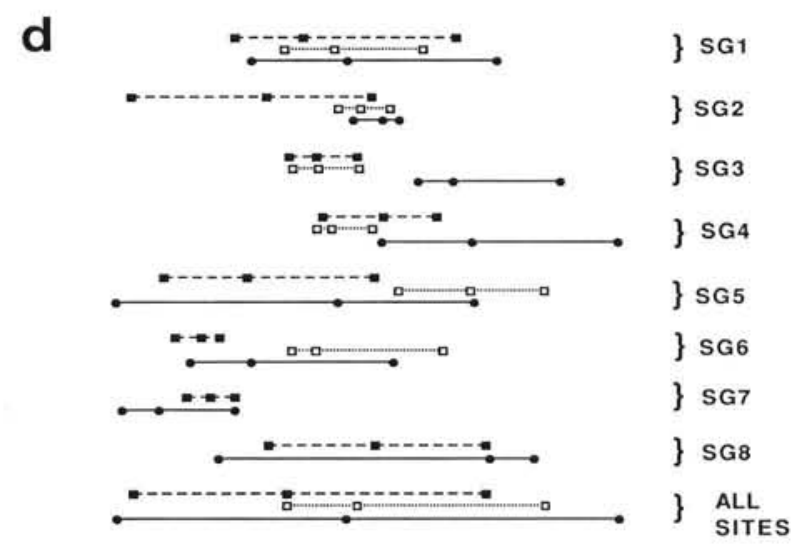

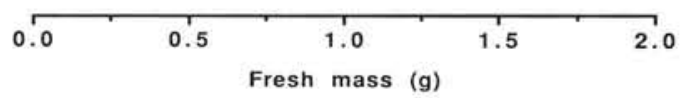

b

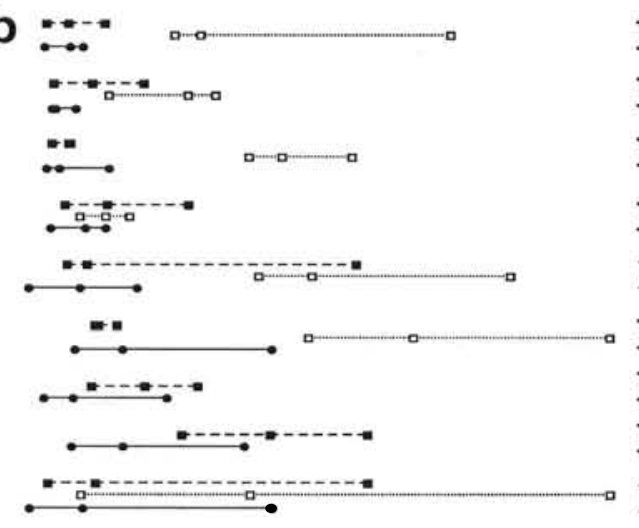

\} SG1

\} SG2

\} SG3

\} SG4

\} SG5

\} SG6

\} SG7

\} SG8

ALL SITES

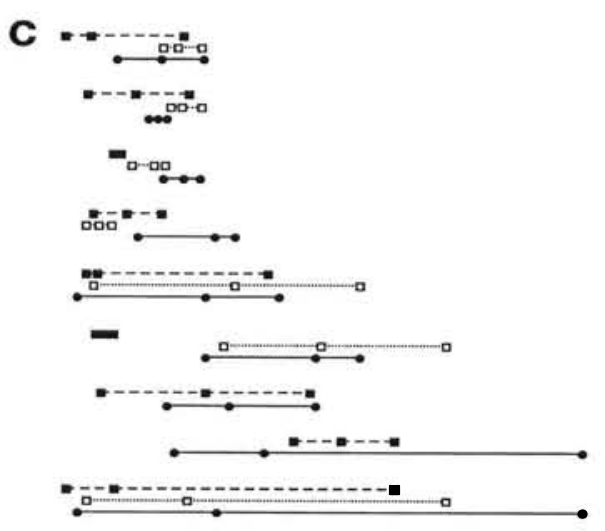

\} SG1

\} SG2

\} SG3

\} SG4

\} SG5

\} SG6

\} SG7

\} SG8

\} ALL
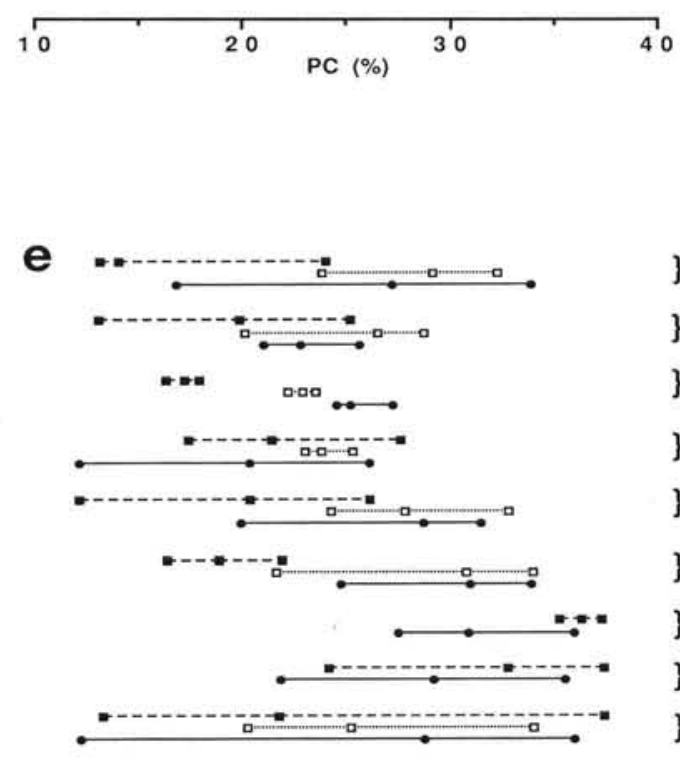

\} SG1

\} SG2

\} SG3

\} SG4

\} SG5

\} sG6

\} SG7

\} SG8

\} ALL

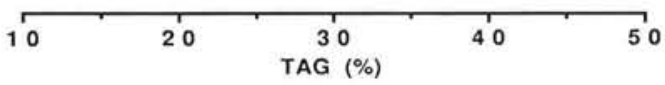

Fig. 3. Euphausia superba. Medians and ranges of males (ᄈ), females (ㅁ) and immatures ( ) for (a) fresh mass, (b) total lipid, (c) lipid percentage fresh mass, (d) percentage PC in total lipid, (e) percentage TAG in total lipid

0.37 to $0.52 \mathrm{~g}$ for immatures. The ranking of krill sizes was consistent for all sites, i.e. females were always slightly larger than males which in turn were larger than immatures. There was a slight tendency for large individuals of one category to co-occur with large individuals of another (Kendall coefficient of rank concordance $=0.491, p=0.172$ ). However this generalisation did not apply universally. Immatures at SG2 had high median mass, but females and males were relatively small (Fig. 3a). No obvious properties of krill size distinguished sites SG7 and SG8 which lacked female krill. Median wet mass for immature krill was lowest of all sites at SG7 but largest at SG8 (Fig. 3a). 


\section{Lipid content}

Results for lipid content of body tissue only are presented here since analysis of extracts from the gut fraction did not differ significantly from that for body tissue. The hepatopancreas lipid comprised approximately $10 \%$ of the krills' overall lipid content and is also included in Fig. 3b, c.

Females (present at SG1 to SG6 only) consistently contained more total lipid (median $70.3 \mathrm{mg}$ ) than both male (median $21.0 \mathrm{mg}$ ) and immature krill (median $17.8 \mathrm{mg}$ ) at these sites (Fig. 3b). However, the ranges of these 3 categories of krill overlapped, i.e. 17.3 to $146.9 \mathrm{mg}$ for females, 9.3 to $87.7 \mathrm{mg}$ for males and 5.1 to $64.2 \mathrm{mg}$ for immatures. For individual sites the pattern of females containing more lipid than males, and males containing more lipid than immatures, still held, although the range of median values was rather more variable (23.9 to $98.7 \mathrm{mg}$ for females, 14.6 to $63.6 \mathrm{mg}$ for males, 11.7 to $27.7 \mathrm{mg}$ for immatures).

The proportion of lipid per unit wet mass varied considerably both between sex and maturity classes and between sites (Fig. 3c). Overall, males contained the lowest proportion of lipid (median value of $1.81 \%$ of wet mass), immatures the highest $(4.16 \%)$ and females an intermediate value $(3.48 \%)$. The variability of lipid content and wet mass meant that lipid proportion showed similar variation within the 3 sex and maturity classes (ranges of 0.72 to $8.20 \%, 1.18$ to $9.40 \%$ and 0.95 to $12.5 \%$ for males, females and immatures respectively). Individual sites did not all conform to the pattern found for the pooled sample (Fig. 3b), with the median proportion of lipid for females exceeding that for immatures at 4 sites, that for males exceeding immatures at 1 site, and males exceeding females at 1 site.

\section{Lipid composition}

Phosphatidylcholine (PC), the major membrane lipid, and triacylglycerol (TAG), the predominant energy storage lipid, were the 2 major lipid classes found in krill at the 8 sites (Fig. 3d, e). Percentage levels of PC tended to be less variable than TAG in all sex and maturity stages (median values for PC being $22.1,25.5$ and $25.0 \%$ for males, females and immatures respectively). Males had slightly lower median proportions of TAG and much greater variability between sites (overall median value $21.7 \%$, range for sites 14.2 to $46.5 \%$ ) than females and immatures (overall medians 30.2 and $35.0 \%$, and site ranges 23.6 to $42.0 \%$ and 22.8 to $44.4 \%$, respectively). These findings are similar to those of Kolakowska (1991) who also noted high variability in the lipid content of male krill. Apart from TAG and PC, the lipid pool also comprised sterols, sterol esters, sphingomyelin, phosphatidylcholine, phosphatidylethanolamine, phosphatidylserine, phosphatidylinositol and cardiolipin.

\section{Multivariate analysis of lipid class composition}

The body lipid-class compositions of all 165 krill from the 8 South Georgia sites were subjected to a multivariate analysis (Principal Component Analysis, PCA; Table 2, Fig. 4 a to d). The first 4 principal components accounted for $78.6 \%$ of the total variation within the data set. Variables making a significant contribution to PC1 were TAG (positive loading) and 4 phospholipids, i.e. phosphatidylserine plus phosphatidylinositol (PS+PI), cardiolipin (CL) and phosphatidylethanolamine (PE), all of which are involved in membrane structure and function. TAG, an energy storage lipid, was one of the 2 most abundant lipid classes in the krill, whereas the other compounds were minor constituents. Proportion of phosphatidylcholine (PC) was contrasted with that of pigment (PIG) and free fatty acids (FFA) in PC2.

Ordination of all of the krill on PC1 and PC2 produced no clear separation of sex-maturity classes (Fig. 4a). Females, males and immatures all showed significant scatter on PC1. Females tended to have more positive scores on PC1 (higher proportion of TAG) than males. PC2 tended to reflect variability amongst immature krill, and females consistently scored negative or near-zero on this axis.

There was no influence of krill size on multivariate lipid composition. Regression of the scores of the 3 sexmaturity classes on individual wet mass produced no significant relationship (Table 3).

Table 2. Euphausia superba. Summary of the key variables contributing to the first 4 principal components from a multivariate, lipid class analysis of krill from 8 sites around South Georgia. Neutral lipids: TAG, triacylglycerol; FFA, free fatty acid; S, sterol; SE, sterol ester. Polar lipids: SM, sphingomyelin; PC, phosphatidylcholine; PE, phosphatidylethanolamine; CL, cardiolipin; PIG, pigment (e.g. astaxanthin, carotenoids and xanthophyll); PS, phosphatidylserine; PI, phosphatidlylinositol

\begin{tabular}{|lclcc|}
\hline PC & Loading & Variable & $\begin{array}{r}\text { Proportion of } \\
\text { variance (\%) }\end{array}$ & $\begin{array}{c}\text { Cumulative } \\
\text { variance (\%) }\end{array}$ \\
\hline PC1 & + & TAG & 35.8 & 35.8 \\
& - & PS+PI, CL, PE & & \\
PC2 & + & PIG, FFA & 20.2 & 56.0 \\
& - & SM+PC & & \\
PC3 & + & SE & 12.6 & 68.6 \\
& - & S & & \\
PC4 & + & LPC, SM+PC & 10.0 & 78.6 \\
& - & S, SE & & \\
\hline
\end{tabular}



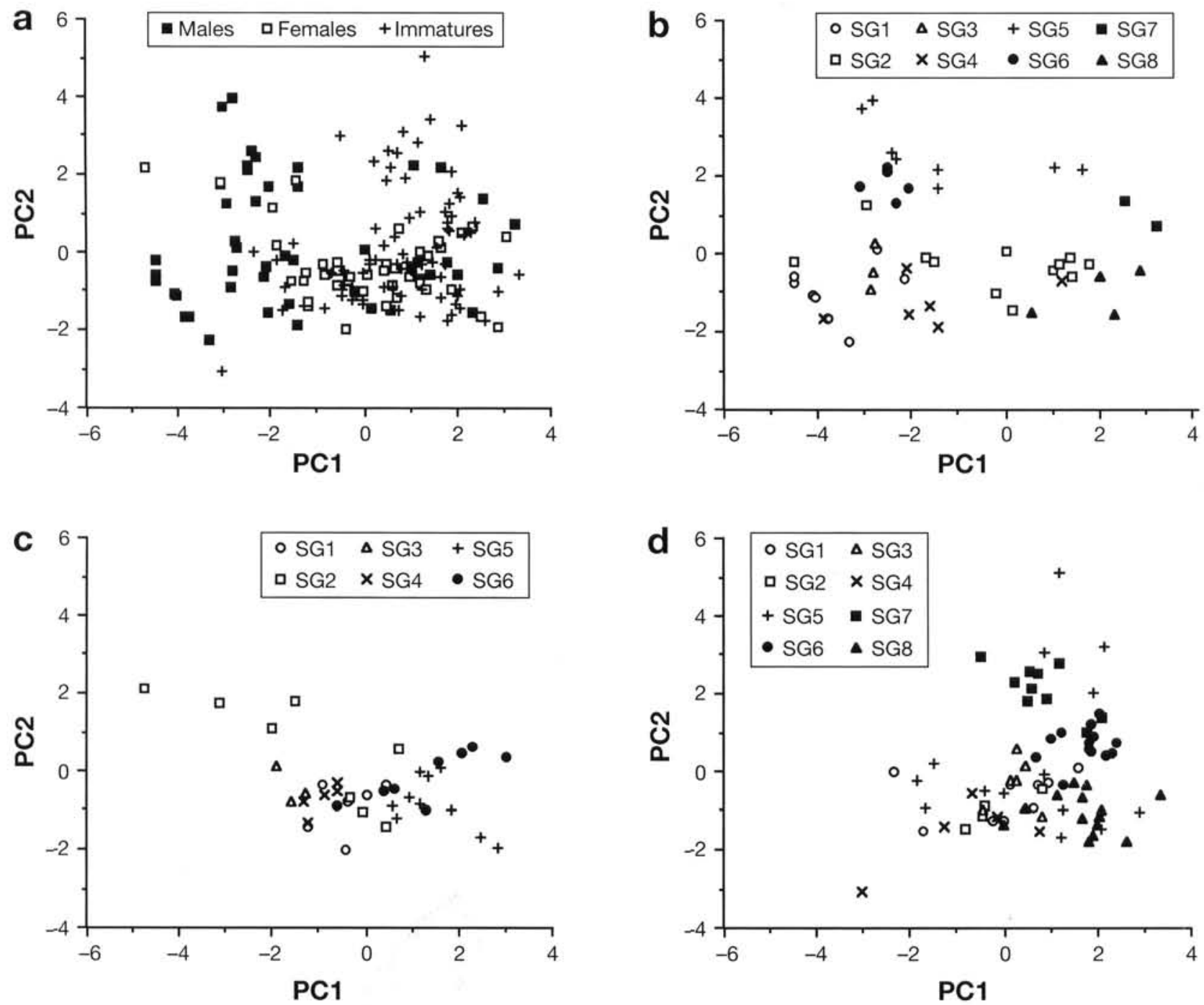

Fig. 4. Euphausia superba. (a) Ordinations of the scores of variables derived from percentage lipid class compositions of males, females and immatures at all sites; (b) sub-plot of males only from the overall PCA at the 8 sites, (c) sub-plot of females only from the overall PCA at the 8 sites, (d) sub-plot of immatures only from the overall PCA at the 8 sites

Although the ordinations did not resolve individual sites, when the ordinations for the sex and maturity stages are separated, there is clearly a pattern in the scores of krill from different sites which is consistent for the 3 sex-maturity classes (Fig. $4 \mathrm{~b}$ to d). Sites SG1 to SG4 tended to have negative scores on PC1, whilst

Table 3. Euphausia superba. Coefficients of determination, $\mathrm{r}^{2}$, for regression analyses of scores on principal components 1 and 2 versus krill body mass

\begin{tabular}{|cccc|}
\hline & Males & Females & Immatures \\
\hline PC1 & 0.02 & 0.04 & 0.01 \\
PC2 & 0.10 & 0.00 & 0.08 \\
\hline
\end{tabular}

sites SG7 and SG8 were positive, and SG5 and SG6 had intermediate scores. The positive scores for krill from sites SG7 and SG8 are noteworthy because females tended to have the most positive scores of the 3 categories, but this category was absent from these 2 sites. No further separation of sites was evident on PC2.

\section{Reproductive investment by krill}

It is possible to discuss the differences in both lipid content and composition between the 3 sex-maturity classes in terms of reproductive investment. Here, we assume that males and females develop from immature individuals of similar composition. 
Female krill

Female krill in this study had a high total lipid content (median value $70.3 \mathrm{mg}$ ind. ${ }^{-1}$, maximum $146 \mathrm{mg}$ ) and, even though the proportion of wet mass accounted for by lipid was lower than for immature krill, the proportion of TAG in total lipid in females was higher than in immature krill. We can only predict a lipid content for a non-reproducing individual as large as the median female krill by extrapolating from the median lipid content of immature individuals. A similar approach has previously been adopted for Calanus helgolandicus (Gatten at al. 1980). An immature krill of the same wet mass as the median value for females $(1.46 \mathrm{~g})$ would contain $55 \mathrm{mg}$ total lipid. On this basis, the female krill in this study tended to contain more lipid (observed median value $70.3 \mathrm{mg}$ ) than predicted from the composition of immature krill.

We can surmise that this apparent surplus lipid may have been associated with egg production. Using published data, we can estimate the lipid requirements for egg production by female krill. Clarke (1980) calculated an annual cost of egg production for a female krill of $2 \mathrm{~g}$ wet mass to be $68 \mathrm{mg}$ total lipid ind. ${ }^{-1} \mathrm{yr}^{-1}$. This value was based on the production of a single batch of 7200 eggs, following the observation that krill spawn once per year around South Georgia (Everson 1976), although repeat spawning is documented for other areas (see Quetin et al. 1993). The amount of lipid estimated to be needed for a single spawning event is more than 4 times the difference between the median total lipid amount in female krill in this study and the predicted somatic lipid content - ca $15 \mathrm{mg}$. In this context, we also note that gravid females were not encountered in our samples. However, it appears that it would have been possible for female krill to accumulate the additional lipid needed for spawning. The mean fatty acid content of particulate material around South Georgia during the study was $100 \mu \mathrm{g} \mathrm{l}^{-1}$, equivalent to $140 \mu \mathrm{g}$ total lipid $\mathrm{l}^{-1}$ (Pond et al. 1993). Taking a value of $10 \mathrm{l} \mathrm{d}^{-1}$ as representative of previously published measurements of feeding and filtration rates (Morris 1984, Quetin et al. 1993), together with our observations of lipid assimilation efficiency (approximately 85\%; Pond 1994), we can calculate that females could accumulate approximately $1 \mathrm{mg}$ total lipid $\mathrm{d}^{-1}$ around South Georgia. Thus it would require little over 1 mo of feeding in the vicinity of South Georgia to accumulate the additional lipid estimated to be required for spawning by Clarke (1980). However, this assumes that $100 \%$ of assimilated lipid is stored for eggs, which is unlikely.
Male krill

Males had a total lipid content similar to that of immature krill and therefore a lower proportionate content than either immatures (smaller) or females (similar size, but more lipid). The proportion of TAG in total lipid was slightly lower in males than in both females and immatures and showed more site-to-site variability. Using the same approach as adopted for female krill, we can estimate a lipid content for 'nonreproducing' median-sized males by extrapolating from data for immature krill. This predicts a lipid content of $44 \mathrm{mg}$ for the median male, whereas the observed median lipid content for male krill in this study was $21 \mathrm{mg}$. Thus, male krill tended to have lower lipid content than expected. The analysis of lipid class composition, including the multivariate analysis, suggests that there was a deficiency of TAG, i.e. the krill were utilising reserve material.

At first sight, it is hard to account for the lipid deficit in male krill by reproductive cost. Compared with female krill, with their very large investment of lipid in reproduction (around twice the somatic lipid content), the costs of male reproduction would appear to be low. However, it is emerging that males in a range of species may incur a similar reproductive investment to that made by females. Van Voorhies (1992) suggested that sperm production by nematodes was more energetically costly that previously thought. Hopkins et al. (1984) have established that the utilisation of lipid by male copepods during reproduction is very substantial and similar to that in females and they noted that males engage in sustained physical activity during reproduction. Kolakowska (1991) also noted that mature male krill contained less lipid than either females or immatures, based on bulk analysis of different sex and maturity stages of Euphausia superba. Although no gravid females were encountered in the samples, male krill are known to attach spermatophores to Stage FA2 females (Watkins et al. 1992), a stage where sexual development is limited. For male krill, successful reproduction also requires sustained effort since females shed spermatophores when they moult and male krill may need to produce 2 spermatophores per week (Watkins et al. 1992). Thus, the cost of spermatophore production coupled with the energetic costs of searching for females and affixing spermatophores could account for the lipid expenditure indicated by our results. Circumstantial support for this is provided by the composition of krill from sites SG7 and SG8 (median value $54 \mathrm{mg}_{\text {ind. }}{ }^{-1}$ ), where females were absent from net hauls. Lipid content in these males was similar to the amount predicted for a non-reproductive krill of similar size. It can be surmised that these krill had not been breeding. Lipid content in males from 
Sites SG7 SG8 was significantly higher than the median lipid content for males from sites SG1 to SG6 (median value $16 \mathrm{mg}$ ) where females were present and where presumably most of the males were breeding.

Thus the reproductive costs to males and females may account for their different lipid content and composition. These costs also differ in the timescale over which lipid is expended. Females accumulate large amounts of lipid for spawning during a summer season (Clarke \& Morris 1983), showing elevated TAG levels and probably building up a lipid reserve which is itself approximately twice the lipid content of a nonreproductive individual of similar size. In contrast, males invest their reproductive effort in a series of events over the season, each of which has a smaller lipid cost but which represents a significant depletion of reserve lipid that would be recovered only after 10 to $20 \mathrm{~d}$ feeding.

\section{Site-to-site variability}

Although differences between sex-maturity classes of krill can explain much of the variability in the data on lipid content and composition, there remains significant and systematic site-to-site variability. Because of the deliberately biased sampling of the net haul at each site, this variability cannot be ascribed either to differences in sex ratio at the sites or to differences in krill size. As the samples were collected over both temporal and spatial scales it is difficult to assess the influence of either of these factors. However, spatial heterogeneity in krill distribution around South Georgia has been documented (Latogursky et al. 1990) and appears to be linked to the pattern of surface water circulation (Grelowski \& Pastuszak 1984). Therefore, variability from site to site possibly results from krill having derived from different sources and having spent variable lengths of time in the vicinity of South Georgia.

Acknowledgements. We thank the officers and crew of the RRS John 'Biscoe' for assistance in collecting samples, Dr Jim Henderson for advice in the laboratory and Prof. Andrew Clarke for useful comments on the manuscript. This work was supported by a NERC Antarctic Special Topic 2 award.

\section{LITERATURE CITED}

Antenzana, T., Ray, K., Melo, C. (1982). Trophic behaviour of Euphausia superba Dana in laboratory conditions. Polar Biol. 1: 77-82

Clarke, A. (1980). The biochemical composition of krill, Euphausia superba Dana, from South Georgia. J. exp. mar. Biol. Ecol. 43: 221-236

Clarke, A., Morris, D. J. (1983). Towards an energy budget for krill: the physiology and biochemistry of Euphausia superba Dana. Polar Biol. 2: 69-86

Ettershank, G. (1983). Age structure and cyclical annual size change in the Antarctic krill, Euphausia superba Dana. Polar Biol. 3: 189-193

Everson, I. (1976). Antarctic krill: a reappraisal of its polar distribution. Polar. Rec. 8: 15-23

Falk-Peterson, S., Hopkins, C. C. E., Sargent, J. R. (1990). Trophic relationships in the pelagic Arctic food web. In: Barnes, M., Gibson, R. N. (eds.) Trophic relationships in the marine environment. Proc. 24th Eur. Mar. Biol. Symp. Aberdeen University Press, Aberdeen, p. 315-333

Folch, J., Lees, N., Sloane-Stanley, G. H. (1957). A simple method for the isolation and purification of total lipid. J. biol. Chem. 226: 497-509

Gatten, R. R., Sargent, J. R., Forsberg, T. E. V., O'Hara, S. C. M. Corner, E. D. S.(1980). On the nutrition and metabolism of zooplankton. XIV. Utilization of lipid by Calanus helgolandicus during maturation and reproduction. J. mar. biol. Ass. U.K. 60: 391-399

Grelowski, A., Pastuszak, M. (1984). Preliminary determination of the occurrence and movement of water masses in the regions of South Georgia Island, the Scotia Sea and the Antarctic Peninsula. Oceanologia 14: 87-111

Hagen, W. (1988). Zur Bedeutung der Lipide im antarktischen Zooplankton. Ber. Polarforsch. 49: 1-129

Henderson, R. J., Sargent, J. R., Falk-Peterson, S. (1981). Lipogenesis in the Arctic euphausid Thysanoessa inermis. Mar. Biol. 63: 235-240

Hopkins, C. C. E., Tande, K. S., Gronvik, S., Sargent, J. R. (1984). Ecological investigations of the zooplankton community of Balsfjorden, northern Norway: an analysis of growth and overwintering tactics in relation to niche and environment in Metridia longa (Lubbock), Calanus finmarchicus (Gunnerus), Thysanoessa inermis (Kroyer) and T. raschi (M. Sars). J. exp. mar. Biol. Ecol. 82: 77-99

Ikeda, T., Dixon, P. (1982). Body shrinkage as a possible overwintering mechanism of the Antarctic krill, Euphausia superba Dana. J. exp. mar. Biol. Ecol. 67: 143-151

Kanda, K., Takagi, K., Seki, Y. (1982). Movement of the larger swarms of Antarctic krill Euphausia superba off Enderby Land during 1976-1977 season. J. Tokyo Univ. Fish. 68: $24-42$

Kils, U. (1979). Swimming speed and escape capacity of Antarctic krill, Euphausia superba. Rep. mar. Res. 27: 264-266

Kolakowska, A. (1991). The influence of sex and maturity stage of krill (Euphausia superba Dana) upon the content and composition of its lipids. Pol. polar Res. 12: 73-78

Latogursky, V. I., Makarov. R.R., Maklygin, L.G. (1990). Distribution, biomass and characteristics of the Euphausia superba fishery round South Georgia. In: Selected scientific papers, 1990. SC-CAMLR-SSP/7. Commission for the Conservation of Marine Living Resources, Hobart, p. 123-145

Laws, R. M. (1985). The ecology of the Southern Ocean. Am. Scient. 73: $26-40$

Marr, J. W. S. (1962). The natural history and geography of Antarctic krill (Euphausia superba Dana). 'Discovery' Rep. 32: 33-464

Marschall, H. P. (1988). The overwintering stratergy of Antarctic krill under the pack ice of the Weddell Sea. Polar Biol. 9: 129-135

Mauchline, J. (1980). The biology of mysids and euphausids. Adv. mar. Biol. 18: 18-681

McClatchie, S. (1988). Food-limited growth of Euphausia superba in Admiralty Bay, South Shetland Islands, Antarctica. Cont. Shelf Res. 8: 329-345 
Morris, D. J. (1984). Filtration rates of Euphausia superba Dana: under- or overestimates? J. Crust. Biol. Spec. Issue 4: 185-197

Morris, D. J., Priddle, J. (1984). Observations on the feeding and moulting of the Antarctic krill, Euphausia superba Dana, in winter. Br. Ant. Surv. Bull. 65: 57-63

Olsen, R. E., Henderson, R. H. (1989). The rapid analysis of neutral and polar marine lipids using double-development HPTLC and scanning densitometry. J. exp. mar. Biol. Ecol. 129: $189-197$

Pond, D. W. (1994). A lipid budget for Antarctic krill (Euphausia superba Dana). Ph.D. thesis, University of Stirling

Pond, D. W., Priddle, J., Sargent, J. R., Watkins, J. L. (1993). Lipid composition of Antarctic microplankton in relation to the nutrition of krill. In: Heywood, R. B. (ed.) University research in Antarctica. British Antarctic Survey, Cambridge, p. 133-139

Price, H. J., Boyd, K. R., Boyd, C. M. (1988). Omnivorous feeding behaviour of the Antarctic krill Euphausia superba. Mar. Biol. 97: 67-77

Quetin, L. B., Ross, R. M., Clarke, A. (1993). Krill energetics: seasonal and environmental aspects of the physiology of Euphausia superba. In: El-Sayed, S. Z. (ed.) Southern

This article was submitted to the editor
Ocean ecology: the BIOMASS perspective. Cambridge University Press, Cambridge, p. 165-184

Rosenberg, A. A., Beddington, J. R., Basson, M. (1986). Growth and longevity of krill during the first decade of pelagic whaling. Nature 324: 152-153

Ross, R. M., Quetin, L. B. (1986). How productive are Antarctic krill? BioSci. 36: 264-269

Ryan, B. F., Joiner, B. L., Ryan, T. A. (1988). MINITAB statistical package software. Reference manual release 8.1 . PWS Publishers, Boston

Sargent, J. R., Parkes, R. J., Mueller-Harvey, I., Henderson, R. J. (1987). Lipid biomarkers in marine ecology. In: Microbes in the sea. Ellis Horwood, Chichester, p. 119-138

Van Voorhies, W. A. (1992). Production of sperm reduces nematode life span. Nature 360: 456-458

Watkins, J. L., Buchholz, F., Priddle, J., Morris, D. J., Ricketts, C. (1992). Variation in reproductive status of Antarctic krill swarms; evidence for a size-related sorting mechanism. Mar. Ecol. Prog. Ser. 82: 163-174

Watkins, J. L., Morris, D. J., Ricketts, C., Priddle, J. (1986). Differences between swarms of Antarctic krill and some implications for sampling krill populations. Mar. Biol. 93: $137-146$

Manuscript first received: January 31, 1994

Revised version accepted: September 29, 1994 